\section{Growing interest in joint venture}

Tokyo

Aт the eleventh hour, two Japanese scientific groups have joined forces to organize a signature-gathering campaign across the country in protest against the US Strategic Defense Initiative (SDI). "Physicists and Mathematicians against SDI" claim to have gathered nearly 3,000 signatures from their colleagues at 145 universities and research institutes across the nation. But it looks as though their protest may be too late.

Last week, a report was submitted to the government from a fact-finding mission of government and business groups (see Nature 320, 294; 1986). The 55member mission had spent ten days in the United States visiting SDI-related research facilities and being briefed on the projects' technical aspects. The mission was the third to visit the United States but the first to include representatives from private companies, itself a pointer to the growing likelihood of participation.

Even before the mission left, business leaders had privately admitted that they had been approached by government and that a generally favourable attitude towards participation had developed. Their main worry, one said, is whether the United States would guarantee that SDI would be a long-term project and not susceptible to sudden cancellation. Without that guarantee, some of the smaller companies would find a commitment to SDI research too risky. Given these behind-the-scenes developments, it is no surprise that the fact-finding mission's eight-page report recommends that Japan take part in the "research phase of SDI".

The report describes SDI as being "nonnuclear" and aimed at abolishing nuclear arms, thus making it compatible with Japan's commitment to peace, enshrined in its constitution and in a Diet resolution never to permit nuclear weapons research. It also stresses that SDI is only a research programme and not a plan for deployment of a defence system. But the chief advantages it sees in participation are more practical.

The report says that progress has already been made in the SDI programme and raises the spectre of a "widening technology gap between the United States and Japan". It also asserts that there will be significant spin-offs for the civilian sector including new air-control radars and remote sensors from the surveillance, acquisition, track, kill and assessment (SATKA) section of SDI. The sensors used to detect heat from rocket exhausts will also find applications in medical sensors. Kinetic-energy weapons research will aid aircraft technology with development of new lightweight materials. And high-power lasers and particle beams can be used in the control of industrial chemical reactions. Altogether, participation will "greatly improve the level of related technologies in this country".

Further consultations will now take place and the final decision made by a group of five cabinet ministers - Defense, International Trade and Industry, Science and Technology, Foreign Affairs and the Cabinet Secretary - along with the Prime Minister. If the answer is positive, as is now expected, they will deter-

\section{Animal protection}

\section{Hamburg} ment) has now passed the amended form of the 1972 Animal Protection Act, introduced by the minister of agriculture, nutrition and forestry in the federal government, Ignaz Kiechle. But it seems unlikely that this development will silence the arguments about the use of animals in experiments that have become common in the past few years.

The new law is the first in a series of measures intended to cover several issues in the field of biological ethics. The dispute about animal experiments, involving industrial companies and scientists on one side and anti-vivisectionists on the other, has been especially fierce in recent months. Individual protesters continue to release experimental animals from institute laboratories, but the bombing of a Cologne laboratory last year has not yet been repeated.

On the face of things, the requirements of the new law are tough, and cover all experiments leading to "pain or injury of the animal", a definition that leaves the use of the organs of dead animals exempt from regulation. In future, investigators will have to justify the need for their use of experimental animals by reference to the investigation of the environmental impact of materials on human beings or the risk of new chemical substances used in medicine. The study of human and vertebrate physiology, like basic research in general, will be a valid justification of experiments.

The new law will require that laboratories where experiments with vertebrates are carried out must appoint animal protection officers (Tierschutzbeauftragten) who must be qualified physicians, veterinarians or zoologists, and who will be required to supervise the application of the new regulations, such as an interdiction of needless duplication of experiments.

The new law forbids the use of animals in the development and testing of
THE Bundestag (the West German parlia- mine the form of Japanese participation. The decision is not expected to be in time for the Tokyo summit of the leaders of industrial nations next week.

With the SDI bandwagon already rolling, it is hard to see that a protest from scientists will have much impact. But many of those who have signed the petition opposing SDI are the very people physicists, mathematicians and computer scientists - who might be expected to be involved in SDI research. They are concerned not only that science is being "increasingly militarized" but also that their research will be diverted into SDI and their publications become restricted "military secrets".

Alun Anderson

\title{
Critics assail West German law
}

weapons; animal tests are also forbidden in the testing of tobacco products, washing powders and cosmetics. While the immediate effect of the new law is to restrict animal experiments, there are provisions to encourage the use of alternative methods to the use of animals in research.

Authorization procedures are to be tightened, chiefly by the appointment of a network of commissions to supervise the authorization procedure. The animal protection organizations will have a powerful influence on the proceedings of these advisory commissions, having established the right to nominate up to a third of the members of the commissions.

The argument is certain to continue, if only because its philosophical and legal implications have not yet been talked out. Some jurists argue that the West German constitution (grundgesetz) is relevant in that a guarantee of human dignity on the principles laid down by Kant and Schopenhauer cannot also be used to justify the killing of countless animals so as to protect people from over-indulgence.

It is significant that there have been several recent decisions of the constitutional court to the effect that the "absolute" right of freedom of research can be in conflict with novel ethical principles, which may imply that guarantees such as this in the 1949 constitution may be mutable in changed circumstances.

Of the political implications of the new developments, there seems no question. The critics of the new law complain that "those to be controlled are the controllers", and their argument is consistent enough to continue at least until the next federal election in January 1987. The Social Democrats have said that they will amend the law if they win power; both they and the Greens also want the law to be extended to cover the extensive keeping of animals as pets. But scientists consistently oppose the new law as an impediment to research.
Jürgen Neffe 